І. М. Кліщ, Н. Я. Потіха, О. С. Ковалик

ДВНЗ “Тернопільський державний медичний університет

імені І. Я. Горбачевського МОЗ Украӥни”

\title{
ДОСВІД ПІДГОТОВКИ ДОКТОРІВ ФІЛОСОФІЇ ЗА ОСВІТНЬО- НАУКОВИМИ ПРОГРАМАМИ У ДЕРЖАВНОМУ ВИЩОМУ НАВЧАЛЬНОМУ ЗАКЛАДІ “ТЕРНОПІЛЬСЬКИЙ ДЕРЖАВНИЙ МЕДИЧНИЙ УНІВЕРСИТЕТ ІМЕНІ І. Я. ГОРБАЧЕВСЬКОГО МІНІСТЕРСТВА ОХОРОНИ ЗДОРОВ'Я УКРАЇНИ”
}

\author{
I. M. Klishch, N. Ya. Potikha, O. S. Kovalyk \\ I. Horbachevsky Ternopil State Medical University \\ THE EXPERIENCE OF DOCTORS’ OF PHILOSOPHY PREPARATION \\ FOR EDUCATIONAL AND SCIENTIFIC PROGRAMS IN THE STATE \\ INSTITUTION OF HIGHER EDUCATION “I. HORBACHEVSKY TERNOPIL \\ STATE MEDICAL UNIVERSITY OF THE MINISTRY \\ OF HEALTH OF UKRAINE”
}

\begin{abstract}
Мета роботи - проаналізувати процес підготовки докторів філософії за освітньо-науковими програмами у ДВНЗ “Тернопільський державний медичний університет імені I. Я. Горбачевського МОЗ України” та встановити відповідність його вимогам чинного законодавства України.

Основна частина. У ДВНЗ “Тернопільський державний медичний університет імені І. Я. Горбачевського МОЗ України” ліцензовано підготовку докторів філософії за спеціальностями: 222 “Медицина”, 226 “Фармація”, 221 “Стоматологія”, 228 “Педіатрія” галузі знань 22 “Охорона здоров’я” та за спеціальністю 091 “Біологія” галузі знань 09 “Біологія”. Підготовка докторів філософії здійснюється за ліцензованими освітньо-науковими програмами та навчальними планами, затвердженими вченою радою університету для кожної спеціальності на правах автономії та самоврядності навчального закладу. Протягом терміну навчання в аспірантурі аспірант повинен виконати індивідуальний навчальний план та захистити дисертаційну роботу.

Висновки. У ДВНЗ “Тернопільський державний медичний університет імені І. Я. Горбачевського МОЗ України” підготовка докторів філософії здійснюється відповідно до чинного законодавства України відповідно до розроблених освітньо-наукових програм у межах ліцензованих спеціальностей. Створено усі належні умови ефективної організації освітньої та наукової складових відповідних програм підготовки.
\end{abstract}

Ключові слова: освітньо-наукова програма; доктор філософії; наукова робота; навчальний процес.

The aim of the work - to analyze the process of doctors' of philosophy preparation for educational and scientific programs in the Ternopil State Medical University and to establish compliance with its requirements of the current legislation of Ukraine.

The main body. The doctors' of philosophy preparation in the following specialties 222 "Medicine”, 226 "Pharmacy”, 221 "Dentistry", 228 "Pediatrics" of the field of knowledge 22 "Health Care" and specialty 091 "Biology" of the field of knowledge 09 "Biology" has been licensed in the State Institution of Higher Education "I. Horbachevsky Ternopil State Medical University of the Ministry of Health of Ukraine”. The doctors' of philosophy preparation are trained by licensed educational programs and curricula approved by the Academic Council of the University for each specialty on the rights of autonomy and self-government of the educational institution. The postgraduate student must complete an individual curriculum and defend his dissertation during the time of education.

Conclusions. The doctors' of philosophy preparation is carried out in accordance with the current legislation of Ukraine in accordance with developed educational and scientific programs within the limits of licensed specialties in the State Institution of Higher Education "I. Horbachevsky Ternopil State Medical University of the Ministry of Health of Ukraine". All proper conditions for the effective organization of the educational and scientific components of the relevant training programs are created.

Key words: educational-scientific program; doctor of philosophy; scientific work; educational process.

() І. М. Кліщ, Н. Я. Потіха, О. С. Ковалик 
Вступ. Динамічний процес інтеграції України до Європейського простору вищої освіти вимагає постійного перегляду та оновлення стандартів підготовки фахівців галузі знань “Охорона здоров'я”, модернізації освітніх програм з урахуванням компетентнісного підходу з метою підвищення якості й ефективності освітнього процесу, що, у свою чергу, зумовить підвищення рівня конкурентоспроможності випускників вищих медичних закладів [1].

У світлі імплементації нового Закону “Про вищу освіту” питання якісної підготовки фахівців на третьому (освітньо-науковому) рівні стоїть особливо актуально. Так, у Статті 5 Закону України “Про вищу освіту” встановлені нові поняття рівнів вищої освіти й окреслена їх відповідність рівням Національної рамки кваліфікацій. Зокрема: “третій (освітньо-науковий) рівень вищої освіти відповідає восьмому кваліфікаційному рівню Національної рамки кваліфікацій і передбачає здобуття особою теоретичних знань, умінь, навичок та інших компетентностей, достатніх для продукування нових ідей, розв'язання комплексних проблем у галузі професійної та/або дослідницькоінноваційної діяльності, оволодіння методологією наукової та педагогічної діяльності, а також проведення власного наукового дослідження, результати якого мають наукову новизну, теоретичне та практичне значення" [2]. Відповідно до дискрипторів Національної рамки кваліфікацій, доктор філософії повинен володіти найбільш передовими концептуальними та методологічними знаннями в галузі науково-дослідної та/або професійної діяльності і на межі предметних галузей, уміти проводити критичний аналіз, оцінку і синтез нових та складних ідей, спілкуватися в діалоговому режимі з широкою науковою спільнотою та громадськістю в певній галузі наукової та/або професійної діяльності, ініціювати інноваційні комплексні проекти, бути лідером та мати повну автономність під час реалізації проектів [3].

Суттєвою особливістю модернізації вищої медичної освіти в Україні є те, що вищим навчальним закладам надане право самостійно розробляти власні освітні (освітньо-професійні чи освітньо-наукові) програми. Адже у Законі України "Про вищу освіту” чітко прописана автономія вищого навчального закладу, що означає його самостійність, незалежність та відповідальність у прийнятті рішень стосовно розвитку академічних свобод, організації освітнього процесу, наукових досліджень, внутрішнього управління, економічної та іншої діяльності, самостійного добору і розстановки кадрів у межах, встановлених даним законодавчим документом [2].
Мета роботи - провести аналіз процесу підготовки докторів філософії за освітньо-науковими програмами у ДВНЗ “Тернопільський державний медичний університет імені I. Я. Горбачевського MO3 України” та встановити відповідність його вимогам чинного законодавства України.

Основна частина. У ДВНЗ “Тернопільський державний медичний університет імені I. Я. Горбачевського МОЗ України” ліцензовано підготовку докторів філософії за спеціальностями: 222 “Медицина”, 226 “Фармація”, 221 “Стоматологія”, 228 “Педіатрія” галузі знань 22 “Охорона здоров’я” та за спеціальністю 091 "Біологія” галузі знань 09 “Біологія” відповідно до наказів МОН України "Про ліцензування освітньої діяльності на третьому (освітньо-науковому рівні)”. Загальний ліцензований обсяг підготовки докторів філософії складає 95 осіб. Підготовка здобувачів вищої освіти ступеня доктора філософії здійснюється в аспірантурі за очною (денною, вечірньою) та заочною формами навчання, а також поза аспірантурою (для осіб, які професійно провадять науково-педагогічну діяльність за основним місцем роботи в університеті).

Підготовка докторів філософії здійснюється за ліцензованими освітньо-науковими програмами та навчальними планами, розробленими відповідно до вимог Порядку підготовки здобувачів вищої освіти ступеня доктора філософії та доктора наук у вищих навчальних закладах (наукових установах), затвердженого Постановою Кабінету Міністрів України від 23.03.2016 року № 261 [4]. Освітньонаукові програми та навчальні плани затверджені вченою радою університету для кожної спеціальності на правах автономії та самоврядності навчального закладу.

Освітньо-наукові програми підготовки докторів філософії визначають передумови доступу до навчання, орієнтацію та основний фокус підготовки, обсяг кредитів Європейської кредитної трансферно-накопичувальної системи (ЄКТС), необхідний для здобуття освітньо-наукового ступеня доктора філософії, перелік загальних та спеціальних (фахових) компетентностей, нормативний i варіативний зміст підготовки фахівця, сформульований у термінах результатів навчання, та вимоги до контролю якості вищої освіти. Освітньо-наукові програми розраховані на чотири академічних роки. Вони включають у себе освітню і наукову складові та передбачають набуття чотирьох основних компетентностей відповідно до Національної рамки кваліфікацій [3, 4]: 
1. Здобуття глибинних знань із спеціальності (групи спеціальностей), за якою (якими) аспірант (ад’юнкт) проводить дослідження, зокрема засвоєння основних концепцій, розуміння теоретичних і практичних проблем, історії розвитку та сучасного стану наукових знань за обраною спеціальністю, оволодіння термінологією $з$ досліджуваного наукового напряму.

2. Оволодіння загальнонауковими (філософськими) компетентностями, спрямованими на формування системного наукового світогляду, професійної етики та загального культурного кругозору.

3. Набуття універсальних навичок дослідника, зокрема усної та письмової презентації результатів власного наукового дослідження українською мовою, застосування сучасних інформаційних технологій у науковій діяльності, організації та проведенні навчальних занять, управління науковими проектами та/або складення пропозицій щодо фінансування наукових досліджень, реєстрації прав інтелектуальної власності.

4. Здобуття мовних компетентностей, достатніх для представлення та обговорення результатів своєї наукової роботи іноземною мовою (англійською або іншою відповідно до специфіки спеціальності) в усній та письмовій формі, а також для повного розуміння іншомовних наукових текстів з відповідної спеціальності.

Загальний обсяг освітньої складової програми складає 48 кредитів ЄКТС, які здобувач наукового ступеня доктора філософії повинен опанувати протягом трьох років навчання. Освітня складова програми оформляється здобувачем наукового ступеня доктора філософії у вигляді індивідуального навчального плану. Усі навчальні плани аспірантури містять узгоджену нормативну частину (36 кредитів ЄKTC). Нормативні навчальні дисципліни забезпечують, зокрема, оволодіння загальнонауковими (філософськими) компетентностями, спрямованими на формування системного наукового світогляду, професійної етики та загального культурного кругозору (6 кредитів ЄКТС); набуття універсальних навичок дослідника, зокрема: усної та письмової презентації результатів власного наукового дослідження українською мовою, застосування сучасних інформаційних технологій у науковій діяльності, організації та проведенні навчальних занять, управління науковими проектами та/або складення пропозицій щодо фінансування наукових досліджень, реєстрації прав інтелектуальної власності (9 кредитів ЄКТС); здобуття мовних компетентностей, достатніх для представлення та обговорення результатів своєї наукової роботи іноземною мовою в усній та письмовій формі, а також для повного розуміння іншомовних наукових текстів з відповідної спеціальності (6 кредитів ЄКТС); здобуття глибинних знань із спеціальності, за якою аспірант проводить дослідження, зокрема засвоєння основних концепцій, розуміння теоретичних i практичних проблем, історії розвитку та сучасного стану наукових знань за обраною спеціальністю (15 кредитів ЄКТС).

Варіативна частина навчальних планів розрахована на 12 кредитів і передбачає теоретичну та практичну підготовку за спеціальністю і спеціалізацією аспіранта. Вона спрямована на формування спеціальних компетентностей. Особливістю підготовки докторів філософії у галузі 22 “Охорона здоров’я” $\epsilon$ велика кількість спеціалізацій за кожною спеціальністю, що вимагає розробки окремих робочих програм із відповідних дисциплін.

Навчальний план аспірантури містить інформацію про графік навчального процесу, перелік та обсяг навчальних дисциплін, послідовність їх вивчення, форми проведення навчальних занять, кількість аудиторних та позааудиторних годин, форми поточного і підсумкового контролю. Проходження освітньої складової аспірантури передбачає лекційні курси, семінарські, практичні заняття, написання курсових робіт, складання іспитів та заліків, індивідуальну самостійну роботу аспіранта, у тому числі самопідготовку у бібліотеці університету 3 використанням наявних інформаційних ресурсів, індивідуальні консультації викладачів тощо.

Відповідно до вимог законодавства, з'явились сучасні та необхідні для аспірантів дисципліни, як-от: “Академічна доброчесність”, “Іноземна мова наукового спілкування”, “Методологія наукового дослідження”, “Клінічна епідеміологія та доказова медицина”, “Філософія науки”, “Педагогіка та психологія вищої школи з основами риторики”, "Методологія і техніки інструментальних та лабораторних досліджень”, “Аналіз сучасних проблем та наукових напрямків в охороні здоров’я” тощо, які $є$ корисними у підготовці майбутнього викладача вищої медичної школи.

Слід відмітити, що в університеті організовано вступну кампанію до аспірантури відповідно до сучасних вимог: вступні випробування включають іспит зі спеціальності у вигляді тестового екзамену (складання тестів множинного вибору типу КРОК) у навчально-науковому відділі тестування знань 
студентів, який є структурним підрозділом університету, а також іспит з іноземної мови в обсязі, який відповідає рівню В2 Загальноєвропейських рекомендацій з мовної освіти.

Наукова складова освітньо-наукової програми передбачає проведення власного наукового дослідження під керівництвом наукового керівника та оформлення його результатів у вигляді дисертаційної роботи. Вона оформляється здобувачем наукового ступеня доктора філософії у вигляді індивідуального плану наукової роботи. Невід’ємною частиною наукової складової аспірантури є підготовка та публікація наукових статей, оприлюднення результатів роботи на наукових конференціях, конгресах, симпозіумах.

Протягом строку навчання в аспірантурі аспірант зобов’язаний виконати усі вимоги освітньо-наукової програми, зокрема здобути теоретичні знання, уміння, навички та інші компетентності, достатні для продукування нових ідей, розв' язання комплексних проблем у галузі професійної та/або дослідницькоінноваційної діяльності, оволодіти методологією наукової та педагогічної діяльності, а також провести власне наукове дослідження, результати якого мають наукову новизну, теоретичне та/або практичне зна-

\section{Список літератури}

1. Розроблення освітніх програм. Методичні рекомендації / [В. М. Захарченко, В. І. Луговий, Ю. М. Рашкевич та ін.]. - К. : ДП “НВЦ “Пріоритети”, 2014. - 120 с.

2. Про вищу освіту : Закон України від 01.07.2014 року № 1556-VII [Електронний ресурс]. - Режим доступу : http://zakon.rada.gov.ua/laws/show/1556-18.

3. Про затвердження Національної рамки кваліфікацій : Постанова Кабінету Міністрів України від 23.11.2011 року № 1341 [Електронний ресурс]. - Режим

\section{References}

1. Zakharchenko, V.M., Luhovyi, V.I., \& Rashkevych, Yu.M. (2014). Rozroblennia osvitnikh prohram. Metodychni rekomendatsii [Working of educational programs. Methodical instructions]. Kyiv: DP “NVTS "Priorytety" [in Ukrainian].

2. [Electronic resource] Pro vyshchu osvitu: zakon Ukrainy vid 01.07.2014 № 1556-VII [About higher education: the law of Ukraine 01.07.2014 No. 1556-VII]. - Retrieved from: http://zakon.rada.gov.ua/laws/show/1556-18 [in Ukrainian].

3. [Electronic resource] Pro zatverdzhennia Natsionalnoi ramky kvalifikatsii: postanova Kabinetu Ministriv Ukrainy vid 23 lystopada 2011 r. No. 1341 [About approval of the National Qualifications Framework: Decree of the Cabinet чення, та захистити дисертацію [4]. Слід відмітити, що обов'язковою умовою допуску аспіранта до захисту дисертаційної роботи $є$ успішне виконання ним індивідуального навчального плану.

В університеті створюються усі передумови для успішного освоєння освітньо-наукових програм здобувачами вищої освіти ступеня доктора філософії завдяки сформованій концепції викладання дисциплін циклів загальної та професійної підготовки, а також створення належних умов виконання наукової складової.

Висновки. У ДВНЗ “Тернопільський державний медичний університет імені І. Я. Горбачевського МОЗ України” підготовка докторів філософії здійснюється відповідно до чинного законодавства України відповідно до розроблених освітньо-наукових програм у межах ліцензованих спеціальностей. Керівництво університету та науково-педагогічні кадри створюють усі належні умови ефективної організації освітньої та наукової складових відповідних програм підготовки. Перспективним напрямом подальшого вдосконалення підготовки докторів філософії є розширення міжнародних програм співробітництва, зокрема шляхом реалізації програм міжнародної академічної мобільності.

доступу : http://zakon5.rada.gov.ua/laws/show/1341-2011$\%$ D0\%BF.

4. Про затвердження порядку підготовки здобувачів вищої освіти ступеня доктора філософії та доктора наук у вищих навчальних закладах (наукових установах) : Постанова Кабінету Міністрів України від 23.03.2016 року № 261 [Електронний ресурс]. - Режим доступу : http:// zakon0.rada.gov.ua/laws/show/261-2016-\%D0\%BF.

of Ministers of Ukraine 23.11.2011 p. No. 1341]. - Retrieved from: http://zakon5.rada.gov.ua/laws/show/1341-2011\%D0\%BF Access mode: http://zakon5.rada.gov.ua/laws/ show/1341-2011-\%D0\%BF. [in Ukrainian].

4. [Electronic resource] Pro zatverdzhennia poriadku pidhotovky zdobuvachiv vyshchoi osvity stupenia doktora filosofii ta doktora nauk u vyshchykh navchalnykh zakladakh (naukovykh ustanovakh): postanova Kabinetu Ministriv Ukrainy vid 23.03.2016 No. 261 [On approval of the order of preparation of applicants for higher education for the degree of doctor of philosophy and doctor of sciences in higher educational establishments (scientific institutions)]. Retrieved from: http://zakon0.rada.gov.ua/laws/show/2612016-\%D0\%BF [in Ukrainian].

Отримано 10.04.18 